\title{
Schistosomiasis mansoni of the appendix in a patient with acute appendicitis
}

\author{
Esquistossomose mansônica do apêndice \\ em paciente com apendicite aguda
}

José Roberto Lambertucci ${ }^{1}$, Luciana Cristina dos Santos Silva ${ }^{1}$ and Dairton Miranda ${ }^{2}$

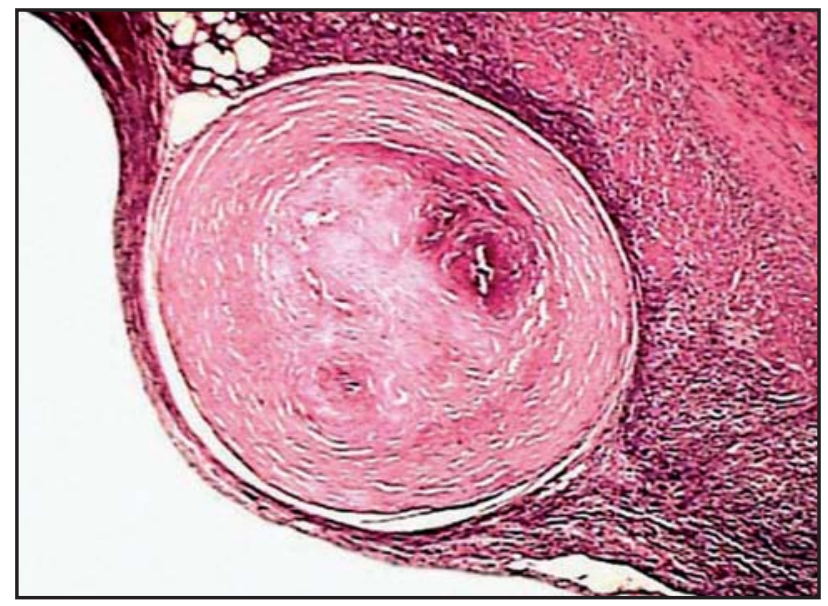

A

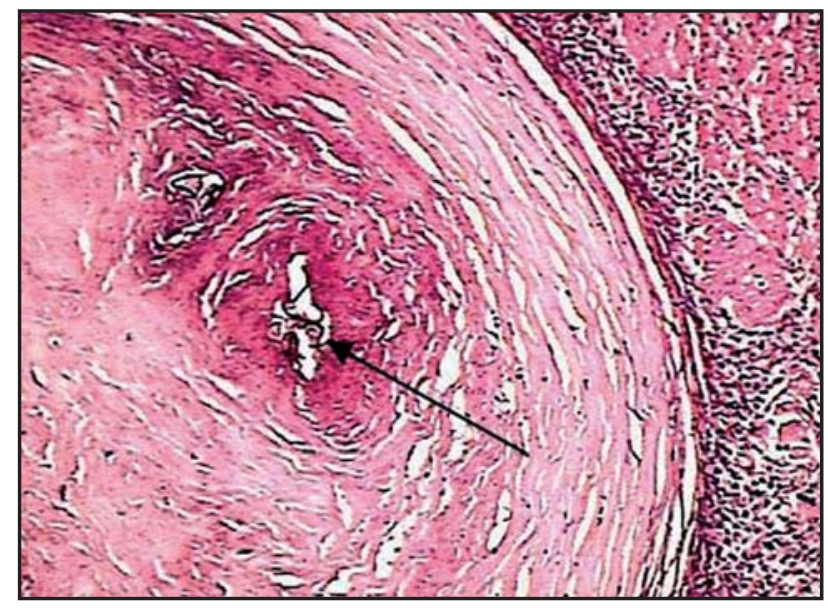

B

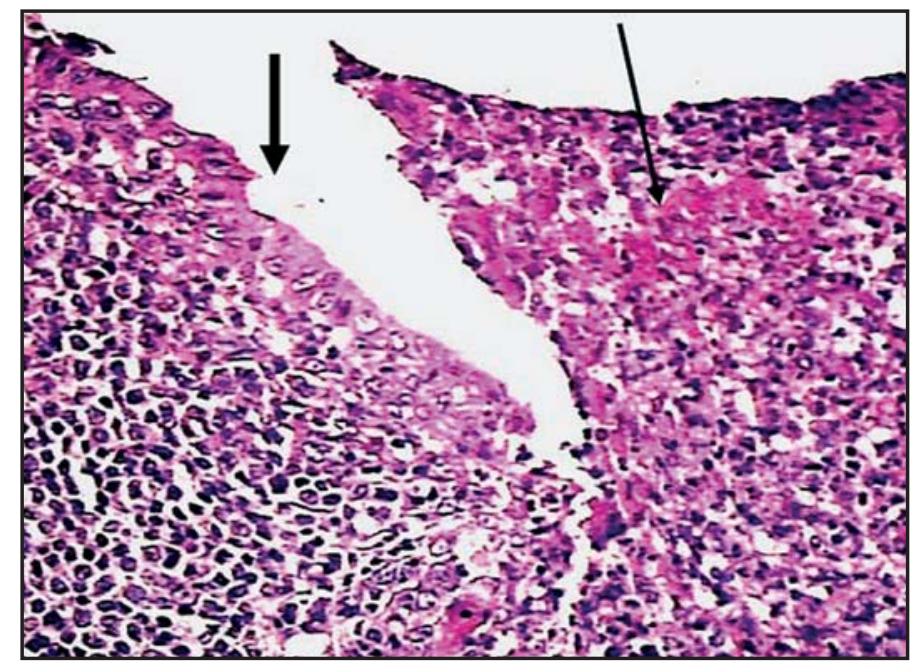

C

1. Serviço de Doenças Infecciosas e Parasitárias, Faculdade de Medicina, Universidade Federal de Minas Gerais, Belo Horizonte, MG. 2. Laboratório de Patologia Dairton Miranda, Belo Horizonte, MG.

Address to: Dr. José Roberto Lambertucci. Dept ${ }^{\circ}$ de Clínica Médica/FM/UFMG. Av. Alfredo Balena 190, 30130-100 Belo Horizonte, MG.

e-mail: lamber@uai.com.br

Recebido para publicação em: 28/02/2008

Aceito em: 07/04/2008 
A 25-year-old man sought the hospital complaining of rightflank pain that had started two days earlier, followed by nausea and fever. Leukocytosis was found in a hemogram, and ultrasound showed thickening of the appendix wall. He underwent an operation and his appendix was removed. Histological examination revealed the presence of a well-formed granuloma containing remnants of Schistosoma mansoni eggshells (Figures A and B). Figure C shows the mucosa of the appendix (thick arrow) and inflammatory infiltrate with predominance of polymorphonuclear neutrophils in the submucosa; areas with fibrinous material are also seen (thin arrow). Parasitological stool examination was positive for Schistosoma mansoni eggs, and the patient was treated with a single oral dose of praziquantel $(50 \mathrm{mg} / \mathrm{kg}$ of body weight, divided into two parts taken with a four-hour interval). Six months later, he was examined at our outpatient clinic and was found to be asymptomatic.

0 paciente, de 25 anos, procurou o hospital com dor no flanco direito de início havia dois dias, seguido de náuseas e febre. 0 hemograma revelou leucocitose e o ultra-som mostrou espessamento da parede do apêndice. Ele foi operado e teve o seu apêndice retirado. 0 exame histológico do apêndice revelou a presença de granuloma bem formado em torno de restos de cascas de ovo de Schistosoma. mansoni (Figuras A e B). Na Figura C, vê-se a mucosa do apêndice (seta grossa) e infiltrado inflamatório com predomínio de polimorfonucleares na submucosa; há ainda áreas com material fibrinoso (seta fina). 0 exame parasitológico das fezes mostrou-se positivo para ovos de Schistosoma mansoni e ele foi tratado com dose única oral de praziquantel $(50 \mathrm{mg} / \mathrm{kg}$ de peso em duas tomadas com intervalo de quatro horas). Seis meses após a cirurgia ele foi examinado em nosso ambulatório e encontrava-se assintomático.

\section{REFERENCES}

1. Gali BM, Nggada HA, Eni EU. Schistosomiasis of the appendix in Maidguri. Tropical Doctor 36: 162-163, 2006.

2. Lambertucci JR, Serufo JC, Gerspacher-Lara R, Rayes AA, Teixeira R, Nobre V, Antunes CM. Schistosoma mansoni: assessment of morbidity before and after control. Acta Tropica 77: 101-109, 2000.

3. Lamps LW. Appendicitis and infections of the appendix. Seminars in Diagnostic Pathology 21: 86-97, 2004. 